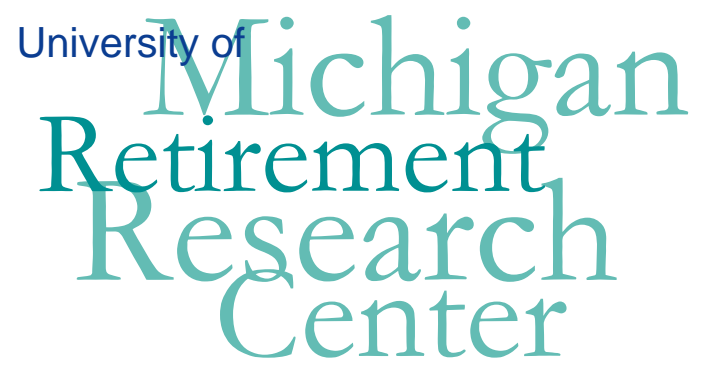

Working Paper WP 2007-150

\title{
The Responsiveness of Private Savings to Medicaid Long Term Care Policies
}

Purvi Sevak and Lina Walker

\begin{tabular}{|l|l|l|}
\hline $\mathrm{M}$ & $\mathrm{R}$ \\
\hline $\mathrm{R}$ & $\mathrm{C}$ & \\
\hline
\end{tabular}$\quad$ Project \#: UM06-18 


\title{
The Responsiveness of Private Savings to Medicaid Long Term Care Policies
}

\author{
Purvi Sevak \\ Hunter College \\ Lina Walker \\ Congressional Budget Office
}

\author{
January 2007 \\ Michigan Retirement Research Center \\ University of Michigan \\ P.O. Box 1248 \\ Ann Arbor, MI 48104 \\ http://www.mrrc.isr.umich.edu/ \\ (734) 615-0422
}

\section{Acknowledgements}

This work was supported by a grant from the Social Security Administration through the Michigan Retirement Research Center (Grant \# 10-P-98362-5-04). The findings and conclusions expressed are solely those of the author and do not represent the views of the Social Security Administration, any agency of the Federal government, or the Michigan Retirement Research Center.

\section{Regents of the University of Michigan}

David A. Brandon, Ann Arbor; Laurence B. Deitch, Bingham Farms; Olivia P. Maynard, Goodrich; Rebecca McGowan, Ann Arbor; Andrea Fischer Newman, Ann Arbor; Andrew C. Richner, Grosse Pointe Park; S. Martin Taylor, Gross Pointe Farms; Katherine E. White, Ann Arbor; Mary Sue Coleman, ex officio 


\title{
The Responsiveness of Private Savings to Medicaid Long Term Care Policies
}

\author{
Purvi Sevak and Lina Walker*
}

\begin{abstract}
This paper examines the extent to which private savings responds to the availability of a social insurance program. We focus on the Medicaid nursing home assistance program and uses variation in state Medicaid policies in the 1960s and 1990s to identify whether household wealth correlates negatively with access to public insurance coverage. We use data from the 1962 and 1970 Survey of Consumer Finances and the 1992 through 2002 Health and Retirement Study. We find that household savings in 1970 was substantially lower in states with easier access to Medicaid assistance and that household savings in the 1990s was lower when access to the Medicaid program was lower.
\end{abstract}

\section{Authors’ Acknowledgements}

*The views expressed in this paper are those of the author and should not be interpreted as those of the Congressional Budget Office. The authors acknowledge financial support from the Social Security Administration though the Michigan Retirement Research Grant, UM06-18. The paper has benefited from comments from Noah Meyerson and participants at the Michigan Retirement Research Center Workshop. Corresponding author: lina.walker@cbo.gov. 


\section{Introduction}

One in five persons over the age of 65 will spend at least a year in a nursing home, and the majority of nursing home residents will have limited private insurance coverage for nursing home costs. ${ }^{1}$ Expenses in a nursing home average around \$60,000 a year (MetLife, 2004) and in the absence of private insurance, individuals must finance these expenses with their own resources or financing from public programs, such as the Medicaid program.

Given the high cost of nursing home care, Medicaid potentially generates strong incentives for older households at risk of incurring nursing home expenses to adjust private savings. Although moral hazard is a general concern for most social insurance programs, it is not clear how large an issue it is for the Medicaid nursing home program. To qualify for Medicaid nursing home assistance, an applicant must meet the state's statutory limit on income and assets. The income and asset thresholds, however, are generally very low. ${ }^{2}$ The stringent financial eligibility criteria for Medicaid nursing home assistance, along with the potential stigma associated with claiming public assistance and concerns about the quality of Medicaid-financed nursing home care, may deter individuals from relying on Medicaid in the future. Given these competing incentives, the overall effect on private savings is uncertain. This paper examines whether, and to what extent, the Medicaid program affects private savings.

Simulation studies have shown that when a social insurance program sets low asset standards for eligibility, savings of households who plan to qualify for the program will be low (Hubbard, Skinner, and Zeldes, 1995). One implication is that private savings of

\footnotetext{
${ }^{1}$ Long-term nursing home care is not a covered benefit for the elderly under the Medicare program, and few households carry private long-term care insurance.

${ }^{2}$ In 1992, the monthly income limits ranged between $\$ 422$ and $\$ 724$, and the asset limit was $\$ 2,000$ for most states (the range was $\$ 1,000$ to $\$ 4,000$ ).
} 
households that plan to use the social insurance program will increase when asset thresholds are raised. The empirical evidence in this regard has been mixed. Gardner and Gilleskie (2006) find a positive relationship between elderly households' net worth and Medicaid's asset thresholds in the state where they reside, and Powers (1998) finds that private savings of low-earning women increased with the increase in Aid to Families with Dependent Children (AFDC) qualifying asset limits in 1981. Hurst and Ziliak (2005), however, find no change in the savings of a similar population (female-headed households with children) with the loosening of asset limits in the 1996 reform of AFDC.

Access to Medicaid may affect private savings by reducing the risk of nursing home expenses. ${ }^{3}$ With lower risk of medical expenses, households reduce private savings. Gruber and Yelowitz (1999) find that when the Medicaid program was expanded to AFDC program recipients, private savings of the newly-eligible population fell by 18 percent. Those results, however, are based on changes in Medicaid eligibility rules that target low-income, workingaged households. The nursing home component of the Medicaid program targets older and potentially, higher income households, and there is limited evidence on whether access to Medicaid nursing home assistance will induce similar reductions in private savings. ${ }^{4}$ This paper explores whether this component of moral hazard is evident with the Medicaid nursing home program.

Walker (2006) finds some evidence that household wealth is lower in states with less

\footnotetext{
${ }^{3}$ Nardi, French, and Jones (2006), Dynan, Hubbard, and Zeldes (2002), Kotlikoff (1986), and Palumbo (1999) find that private savings vary positively with the risk of future medical expenses.

${ }^{4}$ The evidence to date has been indirect. Levin (1995) finds a positive relationship between illiquid assets and health insurance premiums and argues that the ability to self-insure varies negatively with the proportion of illiquid assets in the household's portfolio. Therefore, the relationship suggests households are self-insuring against uninsured medical expenses. Webb (2001) finds no difference in the dis-saving rate between elderly households that anticipate nursing home admission and those that do not. He concludes that there is little evidence that households are saving for nursing home expenses.
} 
restrictive Medicaid eligibility standards and concludes that at least $\$ 24,000$ of retirement wealth is attributable to saving for nursing home expenses. Those results, however, are identified off a policy change that occurred 30 years prior to the date when wealth is observed in the data. ${ }^{5}$ The result of that paper might be biased by unobserved time-varying state effects. To circumvent that issue, this paper focuses on how changes in savings are correlated with contemporaneous policy differences.

The paper examines the savings response from two different time periods. We first look back at the period when Medicaid was introduced - the 1960s. The 1960s began with very few states offering any public assistance and ended with the majority of states offering some public coverage for nursing home care through Medicaid. ${ }^{6}$ Across states, the eligibility standards for Medicaid nursing home assistance varied, providing an additional source of variation in access to public insurance for nursing home expenses. We use data from the 1962 and 1970 Surveys of Consumer Finances (SCF) to compare how household wealth differed across different states before and after Medicaid was introduced. We find substantial differences in wealth that are correlated with the timing of nursing home coverage by Medicaid.

We next examine the effects of Medicaid in the 1990s on private savings, using data from the Health and Retirement Study (HRS). ${ }^{7}$ We exploit variation in whether states include assets that were used to purchase a Medicaid annuity as part of the applicant's “countable” assets. In general, Medicaid disregards some portion of an applicant's assets

\footnotetext{
${ }^{5}$ The household was observed in 1993 and the treatment (Medicaid) was implemented in 1965.

${ }^{6}$ The Medicaid program was introduced in 1965. Prior to Medicaid, some states offered public insurance for nursing home care through the Medical Assistance for the Aged (MAA) program, which was introduced in 1960. Prior to 1960, there was very limited state and local assistance for nursing home care.

${ }^{7}$ There was less state variation in Medicaid eligibility in the 1990s, but we add this period to our study because behavior in the 1960s may not be generalizable to the present.
} 
when determining eligibility. All remaining assets are considered "countable” assets and used to determine eligibility. To qualify for Medicaid, applicants must reduce countable assets to the state's asset threshold (This is sometimes referred to as the Medicaid tax on assets). ${ }^{8}$ Assets that are disregarded are effectively exempt from the Medicaid tax on assets. Cross-state differences in whether the assets used to purchase Medicaid annuities are disregarded generate substantial differences in the effective Medicaid tax on assets. As the effective tax on assets increases, the cost of using Medicaid services increases and the net benefit of the Medicaid program is reduced. Therefore, households facing a higher tax on assets have a lower incentive to apply for Medicaid, and we expect private savings will be higher for these households. We find that households in states with a higher effective Medicaid tax on assets save significantly more.

\section{Did the Introduction of Medicaid Reduce Private Savings?}

Public Assistance for Nursing Home Care in the 1960s

Public assistance for nursing home care was first introduced in 1960 through the MAA program. ${ }^{9}$ Between 1960 and 1965, 20 states participated in the program. In 1965, the Medicaid program was implemented, and by 1971 all states but Arizona had adopted the Medicaid program. ${ }^{10}$ In the 1960s, under the MAA program and then later under the Medicaid program, individuals qualified for state-supported nursing home care if their income and assets were below the state's statutory eligibility thresholds. ${ }^{11}$ The income and

\footnotetext{
${ }^{8}$ In 1971, the asset threshold ranged between $\$ 400$ and $\$ 4,000$.

${ }^{9}$ Prior to 1960 , there was limited nursing home assistance for low-income households. Public assistance was in the form of cash payments for medical care under the Old Age Assistance Program. Assistance was also provided through state- or local-run institutions for the poor, infirmed, and elderly.

${ }^{10}$ The Medicaid program was implemented in Arizona in 1982.

${ }^{11}$ As noted earlier, there were only small differences across states in their statutory limits for income and assets.
} 
asset thresholds were low across the states, but some states allowed individuals to subtract medical expenses from their gross income. The individual would qualify if this net income was below the income eligibility threshold. This means that individuals with high income could qualify for Medicaid coverage if their medical expenses were high enough. These individuals qualified as “medically-needy" recipients. ${ }^{12}$

Given the potentially high level of nursing home costs, the use of the medically-needy criterion substantially raised the effective income eligibility limit in medically-needy states. Thus, in the 1960s substantive variation in Medicaid eligibility existed across states, stemming from whether the state adopted the medically-needy criterion for eligibility. Although some states qualified medically-needy recipients under the MAA program, the scope of coverage for most states was limited. The scope of medically-needy coverage increased under the Medicaid program. In 1966, 18 of the 51 states (including the District of Columbia) qualified medically-needy recipients and by 1970, 28 states covered medicallyneedy recipients. Table 1 shows the medically-needy states in selected years between 1960 and $1970 .^{13}$

\section{Estimation of Savings Effects of Medicaid in the 1960s}

We examine whether there were any changes in household savings as a result of the introduction of social insurance for nursing home expenses. If moral hazard was significant, we will observe reduced household savings after the introduction of Medicaid. However,

\footnotetext{
${ }^{12}$ For example, suppose the income standard is $\$ 400$. Then, in a medically-needy state, the individual qualifies if (income-medical expenses) $\leq \$ 400$; whereas in a non medically-needy state, she qualifies if (income $\leq$ $\$ 400$ ). If nursing home expenses are $\$ 1,000$ a month, this means the individual in a medically-needy state can have as much as $\$ 1,400$ in income and still qualify for assistance.

${ }^{13}$ Since 209(b) states are allowed to deduct medical expenses from income to qualify, in spirit, these states are similar to medically-needy states. As such, I categorize 209(b) states as medically-needy states in Table 1.
} 
simply comparing household wealth before and after 1965 is problematic. Changes in wealth during that period could have also been caused by business cycle fluctuations, changes in other economic factors or policies (such as Medicare, which was introduced in 1965), or differences in cohort saving behavior. Without accounting for these factors, we would spuriously attribute observed differences in wealth to the introduction of the Medicaid program.

We thus exploit the differences across states in medically-needy coverage, described above, to capture additional variation in Medicaid eligibility standards. Figure 1 shows the distribution of medically-needy states in 1966, which is the distribution we adopt in this paper. Households living in states that qualify individuals through the medically-needy criterion face higher effective income thresholds and therefore have greater access to statesupported nursing home coverage than households living in states that do not qualify the medically-needy. Households in states with the medically-needy qualifications need to save less, so their average household wealth should be lower. ${ }^{14}$ Using variation across states and years enables a difference-in-difference estimation.

To identify the effect of the Medicaid medically-needy program on private savings in the 1960s, we use data from the 1962 and 1970 SCF. The SCF surveyed households annually from 1946 to 1971, and each survey is nationally representative of the cross-section of non-institutionalized households at that time. ${ }^{15}$ The strengths of the 1962 and 1970 SCF data are that the data straddle the period when the Medicaid program was implemented; and,

\footnotetext{
${ }^{14}$ The medically-needy criterion might affect savings in the opposite direction. Households in states without a medically-needy program might save less so that they can qualify for Medicaid; households in states with a medically-needy program may save more because they know they will not have to be completely destitute to qualify. Walker (2005) shows that this behavior is more likely to be adopted by households in the lower end of the income distribution and that the medically-needy criterion is less likely to be triggered for these households. ${ }^{15}$ See Federal Reserve Board, Reports on the Surveys of Consumer Finances, Federal Reserve Bulletin, 19471959 for more details about the data.
} 
more importantly, the data include the respondent's state of residence. The SCF data also include the household's economic and demographic characteristics. The limitation of the SCF is that it is not a panel and we cannot observe changes in household savings over time. Instead, we use the SCF to compare the net worth of cross sections of households over time and across states.

In 1962, 2,117 households were interviewed, and in 1970, 2,576 households were interviewed. In 1962, the household unit is defined as a spending unit whereas in 1970, the household unit is defined as a family unit. For comparability across years, we use only single spending-unit households. Limiting the sample further to heads of households gives 901 households from 1962 and 1,743 households from 1970. Because the risk of needing nursing home care tends to manifest among the very elderly, we anticipate that households are more likely to account for that risk in their saving decisions at older ages. Therefore, we constrain the sample to include only households with heads between the ages of 45 and 75. Eliminating all cases with incomplete or missing information yields a final sample of 1,056 households. $^{16}$

Table 2 provides summary statistics of the 1962 and 1970 data. We compare the characteristics of households in 1962 to households in 1970 and the characteristics of households in medically-needy states to households in non medically-needy states. In 1962 and 1970, about three-quarters of households are under the age of 65, around 70 percent of households are married, 70 percent own a home, 4 percent own a farm, and around 10 percent are black. Median household net worth is \$72,600 in 1970 compared to \$66,500 in 1962. A major difference between households in the two samples is the proportion of retired

16 Eliminating cases with zero or negative net worth reduces the sample further to 931 households. 
households. In 1962, only 3 percent of households in the $45-75$ age group are retired, whereas in 1970, 18 percent of households are retired. Households aged 62 and older in the 1970 sample are far more likely to report being retired than similarly aged households in 1962. If differences in economic environment or in cohort behavior are generating the differences in retirement decisions and if retirement decisions affect private savings, then these differences will be absorbed by the time dummy.

Households in medically-needy states are generally similar in observable characteristics to households in non medically-needy states. In both groups, the age of the household head is around 57 years, about 70 percent of households are married, about 20 percent are single female households, about 33 percent have children under the age of 18 years, and about 4 percent of households own a farm. Households in medically-needy states, however, tend to have higher wealth holdings. There is a slightly lower proportion of black households in medically-needy states (11 percent compared to 14 percent), and a higher proportion of households in medically-needy states have 12 or more years of schooling.

One concern in a difference-in-difference (DD) analysis is that there may be unobservable variables that are correlated with the regressor of interest (in this case, the interaction term of medically-needy states and post-Medicaid households. The summary data from Table 2, however, indicate that households living in medically-needy states post Medicaid tend to have higher wealth than other households, which is contrary to the DD prediction we are testing. Furthermore, none of the observable characteristics appear likely to exert a downward bias on the DD estimate.

Using the 1962 and 1970 SCF data, we estimate the following equation using Ordinary Least Squares (OLS): 


$$
\log W_{i t}=\beta_{0}+\beta_{1}\left(M N_{i t} \cdot Y 1970_{i t}\right)+\beta_{2} M N_{i t}+\beta_{3} Y 1970_{i t}+\beta_{4} Z_{i t}+\varepsilon_{i t} .
$$

where $W_{i t}$ is household net worth. ${ }^{17}$ The variable $M N_{i t}$ is a dichotomous variable which is set to one if the household lives in a state that qualifies the medically-needy, $Y 1970_{i t}$ is a dichotomous variable which is set to one if the household was observed in 1970, and $Z_{i t}$ is a vector of control variables that includes age of the household head, marital status, race, presence of children younger than 18, years of schooling of household head, whether the household owns a home or a farm, and changes in median income and median housing values in the state.

The coefficient on the $M N_{i t}$ variable, $\beta_{2}$, captures any time-invariant differences in net worth between states that covered the medically-needy post-Medicaid and those that did not. Thus, it controls for policy endogeneity (for instance, perhaps really poor states were more likely to cover the medically-needy). The coefficient on $Y 1970_{i t}, \beta_{3}$, absorbs average differences in wealth between 1962 and 1970. The coefficient on the $\left(M N_{i t} \cdot Y 1970_{i t}\right)$ term, $\beta_{1}$, is the DD estimator of the effect of social insurance on savings. It measures the average change in household wealth over time between medically-needy and non medically-needy states. For the reasons stated above, we expect that $\beta_{1}$, will be negative: after controlling for policy endogeneity and year fixed effects, we anticipate that household wealth declined after the passage of Medicaid.

If all households across the income distribution were saving for nursing home care, then the difference-in-different estimator, $\beta_{1}$, represents private savings for nursing home

\footnotetext{
${ }^{17}$ The equation was also estimated with log of non-housing net worth as the dependent variable. The sign and magnitude of the estimated coefficient of interest was largely similar; however, the estimated effect was not significant.
} 
expenses. However, as Walker (2006) shows, in the absence of public insurance, only certain households in the middle and upper tail of the income distribution will choose to selfinsure against nursing home expenses. Some households, especially those in the lower tail of the income distribution, will choose not to save for nursing home expenses and rely instead on public or charitable sources of nursing home care. Therefore, the estimated effect represents average private savings for nursing home care across the whole income distribution, and it should be interpreted as the lower bound for middle- to high-income households.

Results: Changes in Private Savings in the 1960s

Table 3 presents the results of the OLS estimates for three different age groups: households aged 45-74, aged 50-74, and aged 55-74. As noted earlier, we anticipate that older households are more likely to account for the risk of nursing home expenses in their saving decisions. If this is the case, then state Medicaid policies should have a larger effect on household wealth and the DD estimate should be larger for older households.

From column 1, we see that the effect of the Medicaid medically-needy program reduces private savings for households in the 45-74 age range, but the effect of the state policy is not statistically significant. However, the effect among older households is significant. Among households in the 50-75 age range, household net worth is 69 percent lower if they live in a medically-needy state. Among even older households (those in the 5574 age range), household net worth is 82 percent lower for those in a medically-needy state. The median household in this age range held about \$72,000 in net worth; therefore, we estimate that the medically-needy provision reduces private savings among these households 
by almost $\$ 60,000$. The Medicaid reimbursement rate for nursing home care in 1971 was about $\$ 30,000$ a year. This suggests that the medically-needy program crowds out 2 years of private savings for nursing home care. ${ }^{18}$

While the 1960s provides some useful variation for testing the savings effects of Medicaid policy, relying on these early years of Medicaid to assess the current effects of Medicaid has number of limitations. First, behavior in the 1960s may not be generalizable to the present. Second, because the SCF data in our analysis are made up of pooled cross sections, some differences in savings may reflect cohort differences. Finally, the empirical strategy assumes that households were saving for nursing home care prior to the MAA and Medicaid programs. Data from the Centers for Medicare and Medicaid Services indicate that private expenditures for nursing home care as a percentage of total health care expenditures in the United States have hovered between 2.5 percent and 3.5 percent of total health care expenditures between 1960 and 2000. Although these data lend validity to the assumption, we nonetheless turn to more recent policies and data from the Health and Retirement Study to study the effects of Medicaid in the 1990s.

\section{Do Medicaid Eligibility Rules Currently Affect Private Savings?}

Public Assistance for Nursing Home Care in the 1990s.

By the 1990s, Medicaid eligibility differences across States are quite small because States’ Medicaid income eligibility standards were mostly equalized. Through enabling federal legislation, states that did not qualify individuals with high medical expenses through

\footnotetext{
${ }^{18}$ All values are adjusted to 2005 dollars, using the CPI-U. The Medicaid nursing home reimbursement rate in New York in 1971 was about $\$ 38,000$ a year, and the reimbursement rate in California was about $\$ 24,000$ a year (Sparer, 1993).
} 
the medically needy program provided alternate routes to expanding coverage to non impoverished households. These non-medically needy states can provide assistance to individuals with income up to 300 percent of the Supplemental Security Income (SSI) benefit amount. ${ }^{19}$ In 1992, the SSI monthly benefit amount was $\$ 422$ for a single household, so individuals with monthly income up to $\$ 1,266$ who were in a nursing home could qualify for Medicaid. ${ }^{20}$ Furthermore, individuals with income above the 300 percent limit can still qualify if the excess income is placed in a trust (the "Miller's trust") and the funds in the trust are applied towards nursing home costs.

Although the effective Medicaid income standards were mostly equalized by the 1990s, there are still differences across states in the effective asset eligibility standards. The statutory asset limit for Medicaid nursing home eligibility in most states is $\$ 2,000 .^{21}$ Individuals who meet the income threshold but who exceed the asset threshold must draw down their assets to the state's asset limit before Medicaid begins to pay benefits (This is sometimes referred to as the Medicaid tax on assets). However, the computation of whether the applicant's assets meet the state's statutory asset limit varies by state; and this variation in how assets are "counted" leads to variation in eligibility standards.

There are two ways in which states vary in the computation of an applicant's assets. First, when a married applicant applies for Medicaid nursing home assistance, each state specifies the amount of household assets that is set aside for the non-institutionalized spouse. This amount ranges from $\$ 17,000$ to $\$ 87,000$. As a consequence, the level of household assets that is attributable to the institutionalized spouse varies by state.

\footnotetext{
${ }^{19}$ This eligibility standard is sometimes referred to as the "special income” rule or "300 percent rule."

${ }^{20}$ The maximum SSI monthly benefit amount for couples in 1992 was $\$ 633$. However, when an individual applies for Medicaid nursing home assistance, the applicant is considered single at that point, even if the applicant is married.

${ }^{21}$ Most states disregard the value of the house, a car, and personal items.
} 
The second cross-state difference in eligibility arises through differences in the definition of countable assets. In recent years, this difference comes largely from differences in whether assets that were used to purchase an annuity are considered part of the household's "countable” assets when the applicant applies for Medicaid assistance. In general, Medicaid disregards some portion of an applicant's assets when determining eligibility. All remaining assets are considered "countable” assets and used to determine eligibility. In order to qualify for Medicaid assistance, applicants must reduce countable assets to the state's asset threshold (this is sometimes referred to as the Medicaid tax on assets). ${ }^{22}$ Assets that are disregarded are, effectively, exempt from the Medicaid tax on assets. Annuities present a challenge for eligibility determination because the purchase of an annuity converts a stock of assets to a flow of income. Thus, assets that would previously have made a household ineligible for Medicaid are not visible. For those assets to be “disregarded” for Medicaid eligibility, federal law requires that the annuity be actuarially fair and irrevocable (also known as a Medicaid annuity). ${ }^{23}$ Assets used to purchase annuities that do not meet these criteria are considered countable assets, and applicants face a penalty period during which they are ineligible for Medicaid coverage. This penalty period is proportional to the purchased value of the annuity. ${ }^{24}$

"Medicaid-compliant" annuities can be structured in a variety of ways that maximize the amount of assets that can be transferred to an heir, thereby circumventing some of the

\footnotetext{
${ }^{22}$ In 1971, the asset threshold ranged between $\$ 400$ and $\$ 4,000$.

${ }^{23}$ Most state Medicaid offices define an actuarially-fair annuity as an annuity with a contract length that matches the SSI life expectancy tables. An irrevocable contract is a contract that is paying or will begin payments within one month of the nursing home application.

${ }^{24}$ Prior to 1993, annuities that were purchased within 24 months of the application were subject to this test (the period of retrospective evaluation was called the "look-back" period). The passage of OBRA 1993 increased the "look-back" period to 36 months. Legislation passed in 2006 raised the "look-back" period further to 60 months and changed the computation of the penalty period.
} 
Medicaid tax on assets. For example, annuities can be structured with a low income stream and a balloon payment at the end of the contract period. If the annuitant dies before the end of the contract period, the remaining payouts and balloon payment will transfer to the remainder beneficiary. In addition, annuity contracts can be specified for longer than the annuitant's expected lifespan; at death, payments continue to the remainder beneficiary. Alternatively, annuities can be purchased for family members. States differ in what types of alternate annuity structures are considered Medicaid-complaint.

Differences in state regulation of annuities can potentially generate substantial crossstate differences in the amount of an applicant's assets that are "taxed" by the Medicaid program. The differences in the resulting "Medicaid tax" may generate differences in savings patterns across states. Households living in states with a higher effective Medicaid tax face higher costs to applying for Medicaid nursing home; therefore, these households have a lower incentive to seek Medicaid assistance. ${ }^{25}$ Even though the tax is effective only at very old ages and only if the individual applies for Medicaid assistance, households should form expectations about the risk of needing Medicaid nursing home assistance, which would affect savings and consumption growth rates. ${ }^{26}$ If so, then households living in states with more restrictive rules regarding Medicaid annuities are less likely to apply for Medicaid assistance and private savings will be higher, on average, in these states.

Alternatively, the Medicaid tax on assets may affect how much households "dissave" in their retirement years. Households in states where it is difficult to protect one's assets

\footnotetext{
${ }^{25}$ Households should also redistribute resources to maximize the expected return of their assets by shifting resources towards assets with lower expected marginal tax rates. Because the expected marginal Medicaid tax rate on annuities is zero until the individual is within the Medicaid "look-back" period, which tends to be when the individual is well past retirement age, we do not expect this incentive to affect private savings rate during the household's labor earning years.

${ }^{26}$ In a consumption Euler equation, this enters as uncertainty about out-of-pocket medical expenses.
} 
through annuities may dissave more and transfer a greater share of their assets at any point in time than households in other states. In this instance, we expect private savings to be lower in states with more restrictive Medicaid annuity rules. To examine the relationship between private savings and Medicaid annuity rules, we examine changes in households wealth in the 1990s using the HRS data.

Estimation of Private Savings for Nursing Home Care in the 1990s

We use the 1992 and 2002 waves of the HRS data to test whether Medicaid affects private savings. The HRS data are representative of non-institutionalized individuals who were aged 51-61 at the time of the first interview in 1992. Respondents have been reinterviewed every two years and continue to be re-interviewed until they die. In 2002, this original sample was aged 61-71. The HRS is useful because it reports the state of residence for each household (through restricted access) and because it follows households over time. These panel data contain measures of household wealth in each wave, allowing us to generate measures of changes in wealth and saving rates. Table 4 provides detailed statistics on wealth and changes in wealth in the HRS data.

We rely on cross-state variation in Medicaid annuity rules during this period to identify any Medicaid-induced changes in savings among households. We sort states into three groups: least restrictive, restrictive, and most restrictive. Figure 2 shows the distribution of states by the level of their Medicaid annuity rules restriction. States that are more restrictive can be regarded as having a higher effective Medicaid tax on assets. ${ }^{27}$ Table 5, which contains summary statistics for our regression variables, shows that 23 percent of

\footnotetext{
${ }^{27}$ We obtain these classifications from Levy, et al. (2006). See also Levy, et al. (2005) for more details on state Medicaid annuity rules.
} 
our sample live in a most restrictive state, 18 percent live in a restrictive state, and 59 percent live in a least restrictive state. We estimate the following equation:

$$
\Delta_{92}^{02} \log W_{i}=\beta_{0}+\beta_{1} \text { Medium }_{j}+\beta_{2} \text { Low }_{j}+\beta 3 \log W_{i}^{92}+\beta_{4} X_{i}+\beta_{5} Z_{j}+\varepsilon_{i}
$$

where the left hand side measures the change in log net worth between 1992 and 2002, controlling for the $1992 \log$ net worth of the household, $W_{i}^{92}$. Because home equity is not considered for Medicaid eligibility, we estimate (2) using both total wealth and wealth excluding home equity. Medium ${ }_{j}$ is a dichotomous variable that is set to one if the household lives in a state with a medium level of restriction on Medicaid annuities and Low $_{j}$ is a dichotomous variable set to one if the household lives in a state with the lowest level of restrictions. Households in the most restrictive states are the reference group.

If greater Medicaid annuity restrictions make Medicaid less desirable and lead to greater self-insurance, we expect the coefficients $\beta_{1}$ and $\beta_{2}$ to be negative. Households in more restrictive states might save more because it is more costly to rely on Medicaid assistance. If, however, higher restrictions on Medicaid annuity leads households save less or dissave faster, we would find $\beta_{1}$ and $\beta_{2}$ to be positive. Households in less restrictive states might save more because they know that they will be able to protect these assets from long-term care expenses.

Because state policies may be correlated with state characteristics that correlate with household savings, we include some state-level controls in the $Z_{j}$ vector. ${ }^{28}$ These are the elderly poverty rate, median elderly income, the mean nursing home daily rate, and the median home price. We also control for household-level characteristics in the $X$ vector.

\footnotetext{
${ }^{28}$ We cannot include state fixed effects because our policy variable does not change over time and given that, we are only observing wealth changes over one time period.
} 
These include age; age squared; dummy variables for self-rated health (good health is the reference group); dummy variables for household type (married is the reference group); years of education; Black race; dummy variables for whether the household had children; owns a home, stocks, or IRAs; dummy variables for whether the household has a pension; or is retired at baseline; the natural log of 1992 household income and the occupation at the last held job. Income and occupation are specifically meant to proxy for lifetime earnings. The analysis is performed at the household level. Individual characteristics such as education, age and occupation are taken at baseline and are from the "household head", defined to be the husband in a married household. If a household divorces between 1992 and 2002, we consider the household to be two separate households for the entire period. We restrict our analysis to households aged 51-58 in 1992 (who are then 61-68 in 2002) to reduce the chance that some households have already entered nursing homes or started dissaving.

Results: Changes in Private Savings in the 1990s

We first estimate (2) among all households aged 51-58 in 1992 who have positive wealth. We estimate the equation using both household net worth and non-housing net worth. Results for total net worth are reported in column 1 of Table $6 .{ }^{29}$ Column 1 shows that the coefficients on Medium and Low are negative for both all wealth and non-housing wealth, indicating that households in states with less restrictive annuity policies save less than those in the most restrictive states. The coefficients are not always statistically significant, however. Because protection of assets from long-term care expenses may be a much bigger

\footnotetext{
${ }^{29}$ Results using non-housing net worth are generally similar and are not reported in this paper.
} 
concern for married households, we next estimate (2) among households married at baseline, and we focus most of our discussion on this sample.

Column 2 of Table 6 presents results for households married at baseline. We include dummy variables indicating the 2002 marital status of the household, since some households may have divorced or become widowed and this may have had a big effect on their wealth. Again, the coefficients on the Medium and Low are negative, suggesting that households in the most restrictive states save more. The coefficients are all statistically significant at either the 5 percent or 10 percent level. The magnitude of the coefficients does not suggest a monotonic relationship between restrictiveness and saving, however: those in Medium restrictive states seem to save the most. The magnitude on the total wealth specification implies that households in the most restrictive states save 18 percent less (or dissave 18 percent more) than households in medium restrictive states and 9 percent less than households in least restrictive states. The estimated effect on non-housing wealth is similar, though the magnitudes are somewhat larger.

The results suggests that very restrictive Medicaid annuity policies lead to greater savings, perhaps because households are more likely to self-insure when Medicaid is more restrictive. There is no evidence that the higher effective Medicaid tax in these states results in reduced saving. The fact that the coefficients increase in magnitude when we restrict the sample to married households are consistent with the fact that that asset protection and thus Medicaid rules should be more important to individuals with a spouse.

Estimated coefficients for covariates are generally not surprising. A higher level of baseline wealth is associated with lower savings rates though greater baseline income, being a homeowner, owning stocks and having an IRA are associated with greater savings rates. 
Better health, more years of education, and staying married through 2002 are all associated with higher savings rates. Having children (who may be adults) is associated with lower savings rates.

If our results truly reflect incentives created by Medicaid, we would expect larger estimated effects among individuals who think they are more likely to need long-term care services. To see if this is the case, we estimate (2) among households in fair or poor health at baseline, among households married at baseline. The sample size is small, but the results in Table 7 provide some evidence of stronger responses among those in poor health. The coefficients on Medium restrictiveness are significantly larger that those estimated among all married households, though the coefficients on Less restrictive states are not significant. Among households in fair or poor health, living in a state with less restrictive Medicaid eligibility is associated with $35 \%$ greater savings in total wealth and $48 \%$ greater saving in non-housing wealth.

\section{Conclusion}

In a recent survey of TIAA-CREF annuitants, respondents indicated that concern about nursing home expenses is one of the primary reasons for saving (Heim, 1992). ${ }^{30}$ Despite the survey response, the average elderly household in 2004 held insufficient funds to finance a long stay in a nursing home. The median married and single elderly households held \$89,000 and \$14,000, respectively, in non-housing assets. At these levels, private

\footnotetext{
${ }^{30}$ Fifty-three percent of respondents indicated that saving for nursing home expenses was extremely or very important where as 49 percent of respondents indicated that saving for retirement consumption was extremely or very important.
} 
savings could finance 18 months of care for a married person and only 3 months of care for an unmarried elderly person. ${ }^{31}$

The shortfall in financial resources for nursing home expenses may reflect moral hazard due to the existence of social insurance. or it could simply be a result of shortsightedness or incomplete planning. Regardless of the reason, the presence of the Medicaid program largely ensures that individuals with insufficient resources will receive services when needed. The implications for public policy, however, differ tremendously depending on the underlying reason for the shortfall. In the case of incomplete planning, Medicaid functions as a safety net for individuals with insufficient funds for nursing home care. If, however, financial shortfall for nursing home expenses is largely due to moral hazard, then public policy could potentially be targeted to restructure saving incentives for nursing home expenses. If incomplete planning explains the financial shortfall, then there should be no systematic correlation between household wealth and Medicaid policies; however, if systematic differences are observed, it provides evidence of moral hazard.

This paper examines the extent to which private savings responds to the availability of Medicaid nursing home assistance. The paper uses variation in state Medicaid policies in the 1960s and 1990s to identify whether household wealth correlates negatively with access to public insurance coverage. The data for the analysis are from the 1962 and 1970 Survey of Consumer Finances and the 1992 through 2002 Health and Retirement Study. The paper finds that household savings in 1970 is substantially lower in states with easier access to Medicaid assistance; and household savings in the 1990s are lower when the cost of

\footnotetext{
${ }^{31}$ Authors own calculations using data from the 1998 Health and Retirement Study. Non-housing assets are computed for households with at least one person between ages 65 and 70 years old. Non-married households include widows and persons who are separated, divorced, or never been married. The corresponding median household net worth for married and single elderly households are $\$ 195,000$ and $\$ 68,000$, respectively.
} 
participating in the Medicaid program is lower. Together, the results provide evidence of moral hazard. 


\section{References}

American Association of Retired Persons (2002). Across the States: Profiles of Long-Term Care. Washington, D.C.

Bruen, B. K., Weiner, J. M., Kim, J. and Miazad, O. (1999). "State Usage of Medicaid Coverage Options for Aged, Blind, and Disabled People.” The Urban Institute Discussion Paper 99-09, Washington, D.C.

Burwell, B. and Rymer, M. P. (1987). "Trends in Medicaid Eligibility: 1975-1985." Health Affairs, pp. 30-45.

Congressional Research Service (1988). Medicaid Source Book: Background Data and Analysis. U.S. Government Printing Office, Washington, D.C.

Congressional Research Service (1993). Medicaid Source Book: Background Data and Analysis (a 1993 Update). U.S. Government Printing Office, Washington, D.C.

Coughlin, T., Ku, L. and Holahan, J. (1994). Medicaid since 1980. The Urban Institute, Washington, D.C.

Dynan, K. E., Skinner, J. and Zeldes, S. P. (2002). "The Importance of Bequests and LifeCycle Saving in Capital Accumulation: A New Answer.” The American Economic Review, Vol. 92(2), pp. 274-278.

Fisher, J. (1953). "Trends in Insitutional Care of the Aged.” Social Security Bulletin, Vol. 16(10), Washington, D.C.

Gardner, Lara and Donna Gilleskie. (2006). "The Effects of State Medicaid Policies on the Dynamic Savings Patterns of the Elderly.” National Bureau of Economic Research Working Paper, No. 12208.

Greenfield (1968). Medicare and Medicaid: The 1965 and 1967 Social Security Amendment. University of California, Berkeley.

Gruber, J. and Yelowitz, A. (1999). "Public Health Insurance and Private Savings.” The Journal of Political Economy, Vol. 107(6), pp. 1249-1274.

Health Care Financing Administration (1970). Characteristics of State Medical Assistance Program under Title XIX of the Social Security Act. U.S. Department of Health, Education, and Welfare, Washington, D.C.

Health Care Financing Administration (1980). National Annual Medicaid Statistics, FY 1973 to 1979. U.S. Department of Health, Education, and Welfare, Washington, D.C.

Health Care Financing Administration (1984, 1986). Analysis of State Medicaid Program Characteristics. U.S. Department of Health, Education, and Welfare, Washington, D.C.

Health Law Project (1972). Medicaid: Volume 5. University of Pennsylvania Law School. 
Heim, Peggy. (1992) "Survey of TIAA-CREF Annuitant Households - Accumulated Net Worth and Current Savings Patterns”. TIAA-CREF Research Dialogues Issue No. 35.

http://eric.ed.gov/ERICDocs/data/ericdocs2/content_storage_01/0000000b/80/26/97/4 3.pdf

Hubbard, R. G., Skinner, J. and Zeldes, S. P. (1995). "Precautionary Saving and Social Insurance.” Journal of Political Economy, Vol. 103, pp. 360-399.

Hurst, E. and Ziliak, J. P. (2006). "Do Welfare Asset Limits Affect Household Savings.” Journal of Human Resources, Vol. 41(1), pp. 46-71.

Kaiser Commission on Medicaid and the Uninsured (2002). The Medicaid Resource Book. The Kaiser Commission, Washington, D.C.

Kotlikoff, L. J. (1989). What Determines Savings. MIT Press, Massachusetts.

Levin, L. (1995). "Demand for Health Insurance and Precautionary Motives for Savings among the Elderly.” Journal of Public Economics, Vol. 57, pp. 337-367.

Levin, L. (1998). “Are Assets Fungible? Testing the Behavioral Theory of Life-Cycle Savings.” Journal of Economic Behavior and Organization, Vol. 36, pp. 59-83.

Levy, L., John Nyman, Mary Gabay, William Riley, and Roger Feldman (2006). "The Cost of Medicaid Annuities.” Health Affairs, Vol. 25(2), pp. 444-451.

Levy, L., John Nyman, Mary Gabay, William Riley, and Roger Feldman (2005). Analysis of the Use of Annuities to Shelter Assets in State Medicaid Programs. Centers for Medicare and Medicaid Services, Washington, D.C.

Liu, K. and Manton, G. (1984). "The Characteristics and Utilization Pattern of An Admission Cohort of Nursing Home Patients.” The Gerontologist, Vol. 24(1), pp. 7076.

Metropolitan Life Insurance Company (2004). MetLife Market Survey on Nursing Home and Home Care Costs 2002. MetLife Mature Market Institute, Westport, CT.

Nardi, Mariacristina, Eric French, and John B. Jones (2006). "Differential Mortality, Uncertain Medical Expenses, and the Saving of Elderly Singles.” National Bureau of Economic Research Working Paper, No. 12554.

Palumbo, M. G. (1999). "Uncertain Medical Expenses and Precautionary Saving Near the End of the Life Cycle.” The Review of Economic Studies, Vol. 66, pp. 395-421.

Powers, E. (1998). "Does Means-Testing Welfare Discourage Saving? Evidence from a Change in AFDC Policy in the United States.” Journal of Public Economics, Vol. 68, pp. 33-53.

Sparer, M.S. (1993). "States in a Reformed Health System: Lessons from Nursing Home Policy.” Health Affairs, Vol. 12(1), pp. 7-20. 
Special Committee on Aging (1963). Medical Assistance for the Aged: The Kerr-Mills Program, 1960-1963. U.S. Government Printing Office, Washington, D.C.

Robyn Stone. (2000) "Long-Term Care for the Elderly with Disabilities: Current Policy, Emerging Trends, and Implications for the Twenty-First Century." Millbank Memorial Fund Report. http://www.milbank.org/0008stone/\#acute

Walker, L. (2006). "Private Savings, Medicaid, and Uncertain Nursing Home Expenses." Congressional Budget Office Working Paper No. 2006-10.

Webb, A. (2001). "The Impact of the Cost of Long-Term Care on the Saving of The Elderly.” Unpublished Manuscript, International Longevity Center, New York. 
Figure 1: Distribution of Medically-Needy States in 1966

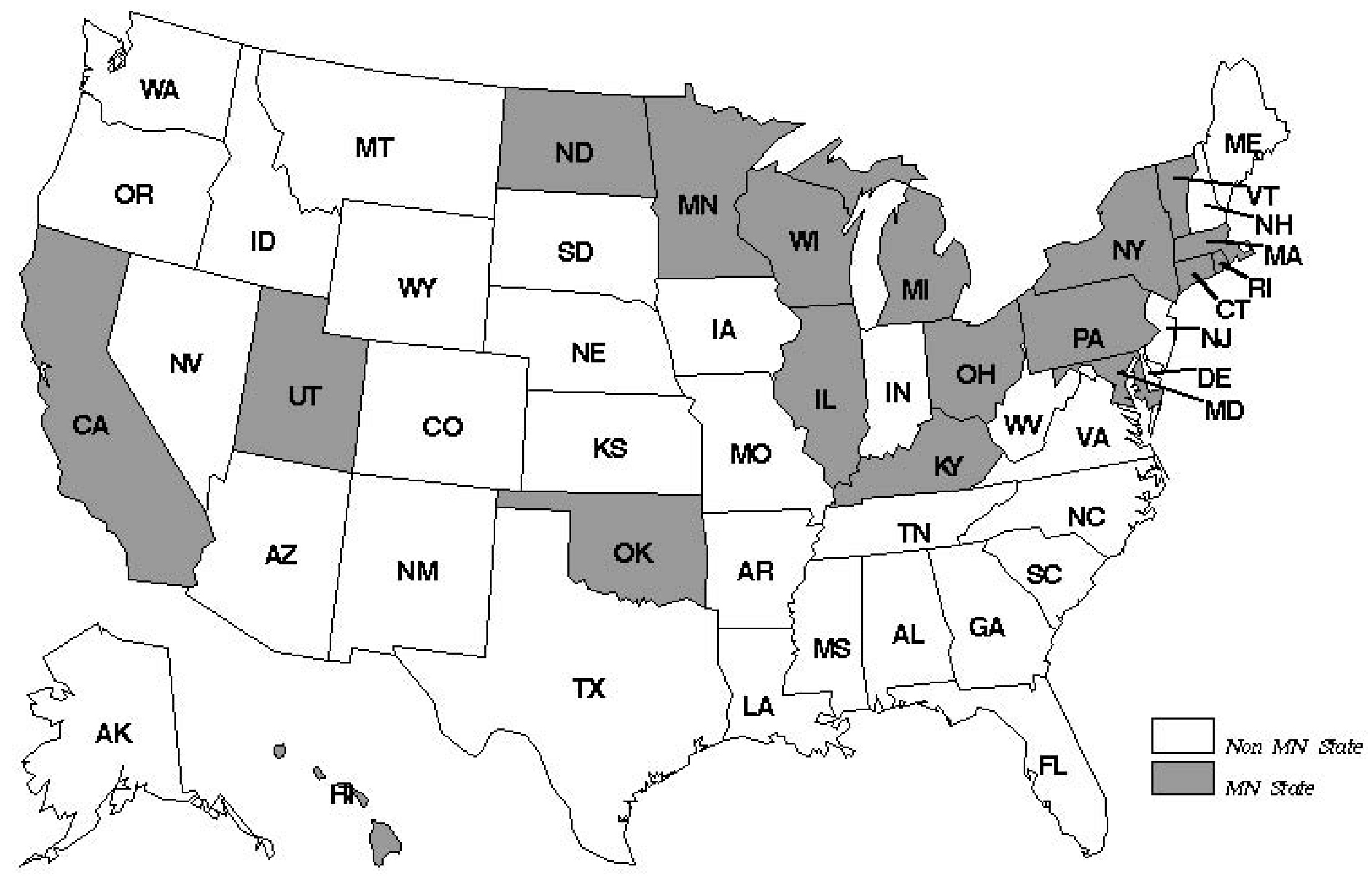


Figure 2: Distribution of Medicaid Annuity Rules

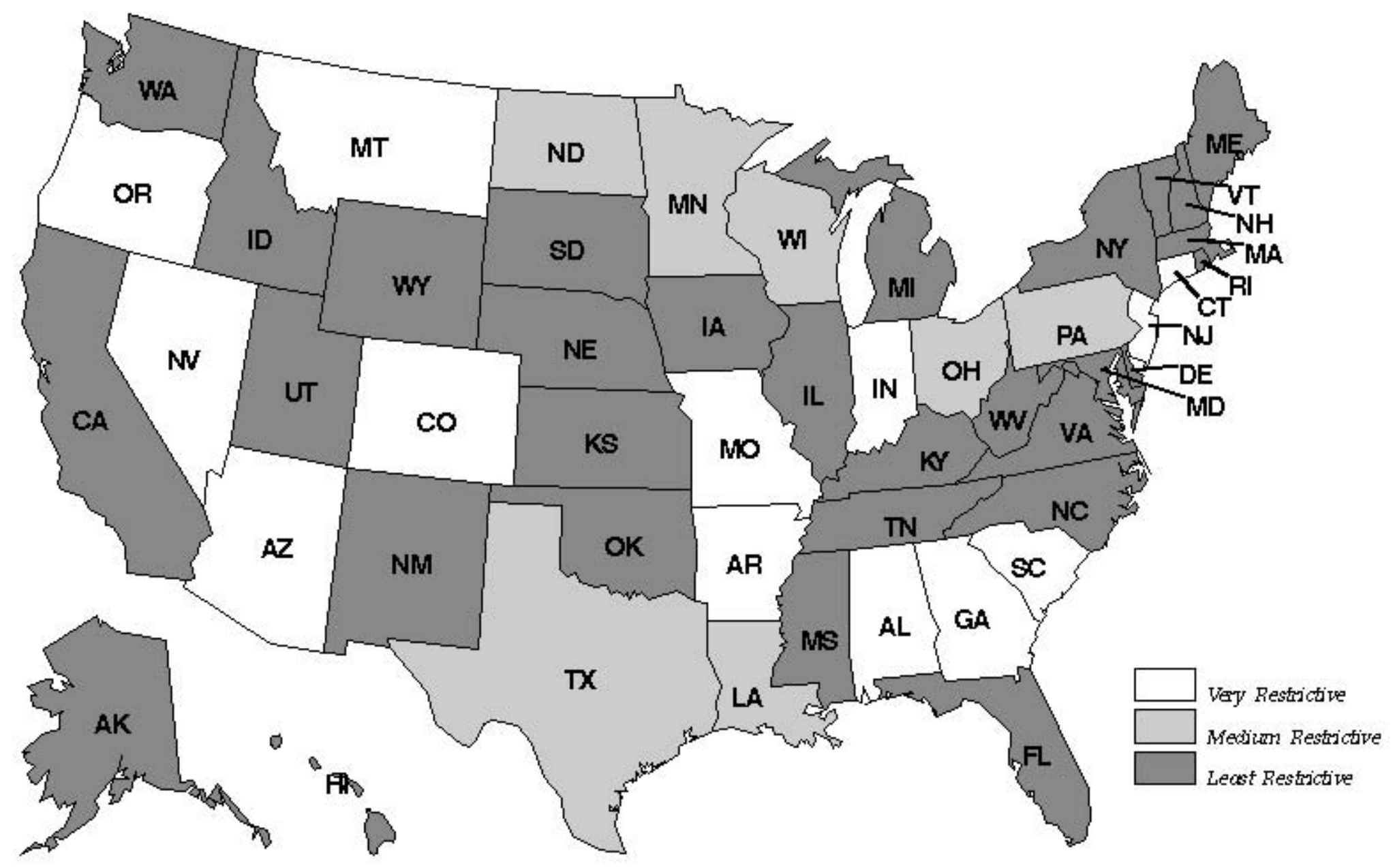


Table 1 : Medically-Needy States between 1960 and 1970

\begin{tabular}{|c|c|c|c|c|}
\hline & $\begin{array}{l}\text { pre-Medicaid } \\
\text { MAA States* }\end{array}$ & $\begin{array}{c}\text { Year } \\
\text { Medicaid }\end{array}$ & Medicaic & States \\
\hline$\underline{\text { State }}$ & $\underline{1963}$ & Implemented & $\underline{1966}$ & 1970 \\
\hline$\overline{A L A B A M A}$ & & 1970 & & \\
\hline ALASKA & & 1972 & --- & \\
\hline ARIZONA & & 1982 & --- & --- \\
\hline ARKANSAS & $x$ & 1970 & & \\
\hline CALIFORNIA & $x$ & 1966 & $x$ & $x$ \\
\hline COLORADO & & 1969 & --- & \\
\hline CONNECTICUT & $x$ & 1966 & $x$ & $x$ \\
\hline DELAWARE & & 1966 & & \\
\hline DISTRICT OF COLUMBIA & $x$ & 1968 & --- & $x$ \\
\hline FLORIDA & & 1970 & --- & \\
\hline GEORGIA & & 1967 & --- & \\
\hline HAWAII & $x$ & 1966 & $x$ & $x$ \\
\hline IDAHO & $x$ & 1966 & & \\
\hline ILLINOIS & & 1966 & $x$ & $x$ \\
\hline INDIANA & & 1970 & --- & $x$ \\
\hline IOWA & & 1967 & --- & \\
\hline KANSAS & & 1967 & --- & $x$ \\
\hline KENTUCKY & $x$ & 1966 & $x$ & $\mathrm{x}$ \\
\hline LOUISIANA & $x$ & 1966 & & \\
\hline MAINE & & 1966 & & \\
\hline MARYLAND & & 1966 & $\mathrm{X}$ & $x$ \\
\hline MASSACHUSETTS & $x$ & 1966 & $x$ & $x$ \\
\hline MICHIGAN & $x$ & 1966 & $x$ & $x$ \\
\hline MINNESOTA & & 1966 & $x$ & $x$ \\
\hline MISSISSIPPI & & 1970 & --- & $x$ \\
\hline MISSOURI & & 1967 & --- & $\mathrm{x}$ \\
\hline MONTANA & & 1967 & --- & \\
\hline NEBRASKA & & 1966 & & $x$ \\
\hline NEVADA & & 1967 & --- & \\
\hline NEW HAMPSHIRE & & 1967 & --- & $x$ \\
\hline NEW JERSEY & & 1970 & & \\
\hline NEW MEXICO & & 1966 & & \\
\hline NEW YORK & $x$ & 1966 & $x$ & $x$ \\
\hline NORTH CAROLINA & & 1970 & & $x$ \\
\hline NORTH DAKOTA & $x$ & 1966 & $x$ & $x$ \\
\hline $\mathrm{OHIO}$ & & 1966 & $x$ & $x$ \\
\hline OKLAHOMA & $x$ & 1966 & $x$ & $x$ \\
\hline OREGON & $x$ & 1967 & --- & \\
\hline PENNSYLVANIA & $x$ & 1966 & $x$ & $x$ \\
\hline RHODE ISLAND & & 1966 & $x$ & $x$ \\
\hline SOUTH CAROLINA & $x$ & 1968 & --- & \\
\hline SOUTH DAKOTA & & 1967 & --- & \\
\hline TENNESSEE & $x$ & 1969 & --- & \\
\hline TEXAS & & 1967 & --- & \\
\hline UTAH & $x$ & 1966 & $x$ & $\mathrm{X}$ \\
\hline VERMONT & & 1966 & $x$ & $x$ \\
\hline VIRGINIA & & 1969 & --- & $x$ \\
\hline WASHINGTON & $\mathrm{X}$ & 1966 & & $x$ \\
\hline WEST VIRGINIA & $x$ & 1966 & & \\
\hline WISCONSIN & & 1966 & $x$ & $x$ \\
\hline WYOMING & & 1967 & --- & \\
\hline
\end{tabular}

Notes:

"X" - the state covers the medically-needy. "--" indicate the state had no Medicaid program that year.

"*" denotes MAA states that covered nursing home care.

Medically-needy states allow individuals to deduct medical expenses from income to qualify for the Medicaid program. Medically-needy states include 209(b) states.

The MAA program is the Medical Assistance for the Aged program. MAA states allowed spend-down. Data compiled from: Bruen, et.al (1999), Burwell and Rymer (1987),

Health Care Financing Administraion (1970, 1980, 1984, 1986), Special Committee on Aging (1963)

Congressional Research Service (1988, 1993), Health Law Project (1972) 
Table 2: Summary Statistics of 1962 and 1970 Survey of Consumer Finances

\begin{tabular}{lrrrrr}
\hline Comparing Across Years & \multicolumn{2}{c}{1962} & \multicolumn{2}{c}{1970} \\
& Mean & Std Dev. & Mean & Std Dev. \\
Household Net Worth* & 151,577 & 296,259 & 190,385 & 578,164 \\
Median Net Worth & 66,461 & & 72,639 & \\
Non-Housing Financial Assets & 95,812 & 254,208 & 121,182 & 508,989 \\
Median Financial Assets & 16,917 & & 12,495 & \\
& & & & 56.9 & 8.4 \\
Age of Head & 56.7 & 8.5 & 0.72 & 0.45 \\
Percent Married Household & 0.70 & 0.46 & 0.22 & 0.42 \\
Percent Single Female Households & 0.20 & 0.40 & 0.78 & 0.42 \\
Percent Black Households & 0.79 & 0.41 & 0.18 & 0.39 \\
Percent Retired Households & 0.03 & 0.17 & 0.32 & 0.47 \\
Percent with Children Under 18 Years & 0.36 & 0.48 & 0.70 & 0.46 \\
Percent Own Home & 0.70 & 0.46 & 0.04 & 0.18 \\
Percent Own Farm & 0.04 & 0.19 & & 0.42 & \\
Percent with 12+ Years of Schooling & 0.37 & & 0.55 & \\
Percent Live in Medically-Needy States & 0.50 & & & 655 & \\
Number of Observations & & & & & \\
\hline
\end{tabular}

\begin{tabular}{|c|c|c|c|c|}
\hline \multirow[t]{2}{*}{ Comparing Across States } & \multicolumn{2}{|c|}{ Medically-Needy State } & \multicolumn{2}{|c|}{$\begin{array}{c}\text { Non } \\
\text { Medically-Needy State }\end{array}$} \\
\hline & Mean & Std Dev. & Mean & Std Dev. \\
\hline Household Net Worth* & $18 \overline{9,901}$ & $\overline{548,424}$ & $15 \overline{9,616}$ & $\overline{416,464}$ \\
\hline Median Net Worth & 84,799 & & 61,634 & \\
\hline Non-Housing Financial Assets & 120,137 & 467,269 & 101,886 & 384,998 \\
\hline Median Financial Assets & 20,222 & & 10,244 & \\
\hline Age of Head & 56.44 & 8.18 & 57.31 & 8.62 \\
\hline Percent Married Household & 0.70 & 0.46 & 0.72 & 0.45 \\
\hline Percent Single Female Households & 0.21 & 0.41 & 0.22 & 0.41 \\
\hline Percent Black Households & 0.07 & 0.26 & 0.14 & 0.35 \\
\hline Percent Retired Households & 0.11 & 0.31 & 0.14 & 0.35 \\
\hline Percent with Children Under 18 Years & 0.33 & 0.47 & 0.33 & 0.47 \\
\hline Percent Own Home & 0.67 & 0.47 & 0.72 & 0.45 \\
\hline Percent Own Farm & 0.03 & 0.17 & 0.04 & 0.21 \\
\hline Percent with $12+$ Years of Schooling & 0.47 & & 0.36 & \\
\hline Percent observed in 1970 & 0.64 & & 0.60 & \\
\hline Number of Observations & 559 & & 497 & \\
\hline
\end{tabular}

Notes: * In 2005 dollars, using CPI-U

Medically-needy states allow individuals to deduce medical expenses from income 
Table 3 : Ordinary Least Square Estimates:

The Effect of Medicaid Medically-Needy Criterion on Private Savings

\begin{tabular}{|c|c|c|c|}
\hline Dependent Variable: Log (Net Worth + 1) & (1) & $(2)$ & (3) \\
\hline Age Group & $\underline{45-74}$ & $\underline{50-74}$ & $\underline{55-74}$ \\
\hline Live in State with Medically-Needy Program & $\begin{array}{c}0.523 \\
(0.269)^{*}\end{array}$ & $\begin{array}{c}0.609 \\
(0.308)^{\star \star}\end{array}$ & $\begin{array}{c}0.699 \\
(0.365)^{*}\end{array}$ \\
\hline Y1970 & $\begin{array}{l}-0.329 \\
(0.241)\end{array}$ & $\begin{array}{l}-0.056 \\
(0.273)\end{array}$ & $\begin{array}{l}0.217 \\
(0.320)\end{array}$ \\
\hline Medically-Needy State * Y1970 & $\begin{array}{l}-0.466 \\
(0.334)\end{array}$ & $\begin{array}{l}-0.689 \\
(0.383)^{*}\end{array}$ & $\begin{array}{l}-0.822 \\
(0.450)^{*}\end{array}$ \\
\hline Age of Head & $\begin{array}{l}0.202 \\
(0.148)\end{array}$ & $\begin{array}{l}-0.477 \\
(0.255)^{*}\end{array}$ & $\begin{array}{l}0.033 \\
(0.472)\end{array}$ \\
\hline Age Square & $\begin{array}{l}-0.001 \\
(0.001)\end{array}$ & $\begin{array}{c}0.004 \\
(0.002)^{*}\end{array}$ & $\begin{array}{l}-0.000 \\
(0.004)\end{array}$ \\
\hline Single Male Household & $\begin{array}{l}-0.754 \\
(0.319)^{\star \star}\end{array}$ & $\begin{array}{l}-0.520 \\
(0.352)\end{array}$ & $\begin{array}{l}-0.526 \\
(0.396)\end{array}$ \\
\hline Single Female Household & $\begin{array}{c}-0.629 \\
(0.207)^{\star \star \star}\end{array}$ & $\begin{array}{c}-0.443 \\
(0.225)^{\star \star}\end{array}$ & $\begin{array}{l}-0.492 \\
(0.253)^{\star}\end{array}$ \\
\hline Black Household & $\begin{array}{c}-1.734 \\
(0.278)^{\star \star *}\end{array}$ & $\begin{array}{c}-2.150 \\
(0.314)^{\star * *}\end{array}$ & $\begin{array}{c}-2.111 \\
(0.381)^{\star \star \star}\end{array}$ \\
\hline Any Children Under 18 Years & $\begin{array}{c}-0.740 \\
(0.199)^{\star \star \star}\end{array}$ & $\begin{array}{c}-0.882 \\
(0.240)^{\star \star \star}\end{array}$ & $\begin{array}{c}-1.076 \\
(0.315)^{\star \star \star}\end{array}$ \\
\hline Schooling: $<=8$ Years & $\begin{array}{c}-1.373 \\
(0.226)^{\star \star *}\end{array}$ & $\begin{array}{c}-1.288 \\
(0.263)^{\star \star \star}\end{array}$ & $\begin{array}{c}-1.443 \\
(0.313)^{\star \star \star}\end{array}$ \\
\hline Schooling: 9-11 Years & $\begin{array}{l}-0.540 \\
(0.252)^{\star \star}\end{array}$ & $\begin{array}{l}-0.684 \\
(0.296)^{\star \star}\end{array}$ & $\begin{array}{c}-0.859 \\
(0.368)^{\star \star}\end{array}$ \\
\hline Schooling: $13+$ Years & $\begin{array}{c}0.542 \\
(0.250)^{\star \star}\end{array}$ & $\begin{array}{c}0.525 \\
(0.302)^{\star}\end{array}$ & $\begin{array}{l}0.342 \\
(0.363)\end{array}$ \\
\hline Own Home & $\begin{array}{c}5.525 \\
(0.192)^{\star \star \star}\end{array}$ & $\begin{array}{c}5.356 \\
(0.217)^{\star \star \star}\end{array}$ & $\begin{array}{c}5.770 \\
(0.256)^{\star \star \star}\end{array}$ \\
\hline Own Farm & $\begin{array}{c}6.780 \\
(0.457)^{\star \star \star}\end{array}$ & $\begin{array}{c}6.403 \\
(0.527)^{\star \star \star}\end{array}$ & $\begin{array}{c}6.739 \\
(0.684)^{\star \star \star}\end{array}$ \\
\hline State Controls & Yes & Yes & Yes \\
\hline Constant & $\begin{array}{l}0.718 \\
(4.305)\end{array}$ & $\begin{array}{c}22.023 \\
(7.765)^{\star \star \star}\end{array}$ & $\begin{array}{c}5.208 \\
(15.090)\end{array}$ \\
\hline Observations & 1056 & 781 & 584 \\
\hline R-squared & 0.57 & 0.57 & 0.59 \\
\hline
\end{tabular}

Data: 1962 and 1970 survey of Consumer Finances.

State controls include changes in median income and median housing values in the state.

Medically-needy states allow individuals to deduce medical expenses from income to meet the state's income threshold.

Standard errors in parentheses. * significant at 10\%; ** significant at 5\%; *** significant at $1 \%$ 
Table 4: Detailed Destribution of Wealth Variables, Among Households Interviewed in 1992 and 2002

\begin{tabular}{|c|c|c|c|c|c|c|}
\hline & Sample Size & $\underline{\text { Mean }}$ & $\underline{\text { Standard Deviation }}$ & 25th \%ile & $\underline{50 \text { th \%ile }}$ & 75th \%ile \\
\hline \multicolumn{7}{|l|}{ All Wealth } \\
\hline 1992 Wealth & 4,198 & 214,162 & 491,134 & 24,000 & 84,025 & 210,100 \\
\hline 2002 Wealth & 4,230 & 351,612 & $1,039,165$ & 35,000 & 137,850 & 375,900 \\
\hline $\begin{array}{l}\text { Change in Wealth } \\
\text { Natural Log }\end{array}$ & 4,198 & 138,783 & 953,596 & $-4,700$ & 35,875 & 172,000 \\
\hline In 1992 Wealth & 3,819 & 11.29 & 1.71 & 10.55 & 11.50 & 12.35 \\
\hline In 2002 Wealth & 3,912 & 11.68 & 1.91 & 10.90 & 11.98 & 12.91 \\
\hline Change in In Wealth & 3,653 & 0.44 & 1.34 & -0.10 & 0.51 & 1.10 \\
\hline \multicolumn{7}{|c|}{ Non-Housing or Business Wealth } \\
\hline 1992 Wealth & 4,198 & 111,355 & 321,370 & 4,000 & 26,200 & 96,000 \\
\hline 2002 Wealth & 4,230 & 203,867 & 833,983 & 5,000 & 42,000 & 187,736 \\
\hline $\begin{array}{l}\text { Change in Wealth } \\
\text { Natural Log }\end{array}$ & 4,198 & 93,580 & 792,157 & $-7,000$ & 7,850 & 86,000 \\
\hline In 1992 Wealth & 3,666 & 10.33 & 1.91 & 9.21 & 10.53 & 11.65 \\
\hline In 2002 Wealth & 3,728 & 10.73 & 10.73 & 9.43 & 11.00 & 12.30 \\
\hline Change in In Wealth & 3,383 & 0.46 & 1.62 & -0.43 & 0.55 & 1.40 \\
\hline
\end{tabular}


Table 5: Summary Statistics of Regression Variables for HRS Regression Sample

\begin{tabular}{|c|c|c|}
\hline & Mean & Std. Dev. \\
\hline Change in 2002-1992 In wealth & 0.45 & 1.33 \\
\hline Change in 2002-1992 In wealth (non-housing) & 0.47 & 1.60 \\
\hline Age & 54.47 & 2.31 \\
\hline Health=Excellent/Very Good & 0.56 & 0.50 \\
\hline Health=Fair/Poor & 0.16 & 0.36 \\
\hline Years of Education & 12.56 & 3.07 \\
\hline Black Race & 0.14 & 0.35 \\
\hline Has Children & 0.94 & 0.24 \\
\hline Homeowner & 0.83 & 0.38 \\
\hline Stock Holder & 0.31 & 0.46 \\
\hline Has IRA & 0.43 & 0.49 \\
\hline Has Pension & 0.48 & 0.50 \\
\hline Retired & 0.07 & 0.26 \\
\hline Houshold Income (levels) & 54,737 & 52,316 \\
\hline In Household Income & 10.61 & 0.84 \\
\hline \multicolumn{3}{|l|}{ Household Type } \\
\hline Married & 0.73 & \\
\hline Single Male & 0.10 & \\
\hline Single Female & 0.18 & \\
\hline \multicolumn{3}{|l|}{ State Characteristics } \\
\hline Elderly Poverty Rate & 11.10 & 2.88 \\
\hline Median Elderly Income & 36,641 & 4,100 \\
\hline Median Home Price & 123,479 & 40,637 \\
\hline Mean Daily Nursing Home Price & 155.26 & 37.80 \\
\hline \multicolumn{3}{|l|}{ State Annuity Policy } \\
\hline Most Restrictive & 0.23 & \\
\hline Restrictive & 0.18 & \\
\hline Least Restrictive & 0.59 & \\
\hline Sample Size & 3,607 & \\
\hline
\end{tabular}


Table 6: Ordinary Least Squares Estimates:

The Effect of Medicaid Annuity Rules on Private Savings

\begin{tabular}{|c|c|c|}
\hline $\begin{array}{l}\text { Dependent Variable: } \\
\text { Change in Log Net Worth (2002-1992) }\end{array}$ & $\begin{array}{c}\text { (1) } \\
\text { Full Sample } \\
\end{array}$ & $\begin{array}{c}\text { (2) } \\
\text { Married Only }\end{array}$ \\
\hline Log Net Worth in 1992 & $\begin{array}{l}-0.527 \\
(0.018) * * *\end{array}$ & $\begin{array}{l}-0.518 \\
(0.021)\end{array}$ *** \\
\hline Medium Medicaid Annuity Restrictions & $\begin{array}{l}-0.137 \\
(0.064) \text { ** }\end{array}$ & $\begin{array}{l}-0.185 \\
(0.067)\end{array}$ *** \\
\hline Low Medicaid Annuity Restrictions & $\begin{array}{r}-0.057 \\
(0.050)\end{array}$ & $\begin{array}{c}-0.093 \\
(0.053)\end{array}$ \\
\hline Age & $\begin{array}{r}-0.056 \\
(0.472)\end{array}$ & $\begin{array}{r}-0.231 \\
(0.497)\end{array}$ \\
\hline Age Squared & $\begin{array}{r}0.000 \\
(0.004)\end{array}$ & $\begin{array}{r}0.002 \\
(0.005)\end{array}$ \\
\hline Health: Excellent or Very Good & $\begin{array}{c}0.179 \\
(0.047)\end{array}$ *** & $\begin{array}{r}0.080 \\
(0.050)\end{array}$ \\
\hline Health: Fair or Poor & $\begin{array}{l}-0.150 \\
(0.064)\end{array}$ & $\begin{array}{l}-0.189 \\
(0.068)\end{array}$ \\
\hline Single Male Household & $\begin{array}{r}0.035 \\
(0.072)\end{array}$ & $\begin{array}{l}-0.653 \\
(0.092)\end{array}$ *** \\
\hline Single Female Household & $\begin{array}{l}-0.202 \\
(0.061)\end{array}$ & $\begin{array}{l}-0.595 \\
(0.068)\end{array}$ *** \\
\hline Years of Education & $\begin{array}{c}0.046 \\
(0.009)\end{array}$ & $\begin{array}{c}0.048 \\
(0.009)\end{array}$ *** \\
\hline Black & $\begin{array}{l}-0.106 \\
(0.060) *\end{array}$ & $\begin{array}{r}-0.093 \\
(0.069)\end{array}$ \\
\hline Have Children & $\begin{array}{r}-0.123 \\
(0.084)\end{array}$ & $\begin{array}{r}-0.197 \\
(0.121)\end{array}$ \\
\hline Own Home & $\begin{array}{c}0.420 \\
(0.064)\end{array}$ *** & $\begin{array}{c}0.353 \\
(0.075)\end{array}$ *** \\
\hline Own Stocks & $\begin{array}{c}0.215 \\
(0.048)\end{array}$ & 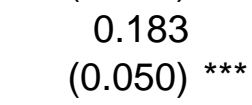 \\
\hline Own IRA & $\begin{array}{c}0.334 \\
(0.047)\end{array}$ *** & $\begin{array}{c}0.342 \\
(0.049)\end{array}{ }^{* \star *}$ \\
\hline Pension Coverage & $\begin{array}{c}0.114 \\
(0.045) * *\end{array}$ & $\begin{array}{r}0.032 \\
(0.048)\end{array}$ \\
\hline Retired & $\begin{array}{r}-0.002 \\
(0.081)\end{array}$ & $\begin{array}{r}-0.082 \\
(0.079)\end{array}$ \\
\hline Log Household Income & $\begin{array}{c}0.170 \\
(0.032) * * *\end{array}$ & $\begin{array}{c}0.154 \\
(0.037)^{* * *}\end{array}$ \\
\hline State Controls & Yes & Yes \\
\hline Observation & 3,607 & 2,624 \\
\hline R-squared & 0.226 & 0.258 \\
\hline
\end{tabular}

Data: 1992 and 2002 Health and Retirement Study.

Omitted variable: states with very restrictive Medicaid annuity rules.

State controls include elderly poverty rate, median elderly income, the mean nursing home daily rate, and the median home price

Standard errors in parentheses. * significant at 10\%; ** significant at 5\%; $* \star *$ significant at $1 \%$ 


\section{Table 7: Among Individuals Most likely to Apply for Medicaid Assistance The Effect of Medicaid Annuity Rules on Private Savings}

\begin{tabular}{|c|c|c|}
\hline Dependent Variable: & $\begin{array}{l}\text { Change in^ } \\
\text { Log Net Worth }\end{array}$ & $\begin{array}{c}\text { Change in }{ }^{\wedge} \\
\text { Log Non-Housing Net Worth }\end{array}$ \\
\hline Log Net Worth in 1992 & $\begin{array}{l}-0.546 \\
(0.065)\end{array}$ & $\begin{array}{l}-0.671 \\
(0.0623) * * *\end{array}$ \\
\hline Medium Medicaid Annuity Restriction & $\begin{array}{r}-0.353 \\
0.217\end{array}$ & $\begin{array}{l}-0.480 \\
(0.261) \text { * }\end{array}$ \\
\hline Low Medicaid Annuity Restriction & $\begin{array}{r}-0.041 \\
(0.172)\end{array}$ & $\begin{array}{r}-0.122 \\
(0.201)\end{array}$ \\
\hline $\mathrm{n}$ & 392 & 336 \\
\hline R-squared & 0.326 & 0.402 \\
\hline
\end{tabular}

Data: 1992 and 2002 Health and Retirement Study. ${ }^{\wedge}$ - change between 1992 and 2002

Omitted variable: states with very restrictive Medicaid annuity rules.

Standard errors in parentheses

* significant at 10\%; ** significant at $5 \%$; ${ }^{* *}$ significant at $1 \%$ 